\title{
Insulin-Like Growth Factor-I Protects Axotomized Rat Retinal Ganglion Cells from Secondary Death via PI3-K-Dependent Akt Phosphorylation and Inhibition of Caspase-3 In Vivo
}

\author{
Pawel Kermer, Nikolaj Klöcker, Monika Labes, and Mathias Bähr \\ Department of Neurology, Medical School, University of Tübingen, 72076 Tübingen, Germany
}

Recently we have shown that the majority of retinal ganglion cells (RGCs) dies via activation of caspase-3 after transection of the optic nerve $(\mathrm{ON})$ in the adult rat. In the present study we investigated whether insulin-like growth factor-I (IGF-I), an important factor in retinal development, prevents secondary death of RGCs after axotomy. Moreover, we studied potential intracellular mechanisms of IGF-mediated neuroprotection in more detail. Our results indicate that intraocular application of IGF-I protects RGCs from death after ON transection in a dosedependent manner. We show reduced caspase-3 activity as one possible neuroprotective mechanism of IGF-I treatment in vivo. Caspase-3 mRNA expression remained unchanged. Because caspase inhibition can be mediated by Akt in vitro, we examined phosphorylation of Akt after axotomy and under IGF treatment. Western blot analysis revealed decreased Akt phos-

Insulin-like growth factor-I (IGF-I) was originally discovered as serum-derived "sulfation-factor activity" (Salmon and Daughaday, 1957) and belongs to a group of polypeptide hormones called somatomedins (Daughaday et al., 1972; Daughaday and Rotwein, 1989). The biological actions of IGF-I are mainly mediated by the IGF-I receptor, which contains a tyrosine kinase domain responsible for the phosphorylation of intracellular signal transduction proteins (Ullrich et al., 1986). Throughout the last decade, a multitude of in vitro studies was performed to investigate the trophic actions of IGF-I on various neuronal cell types (for review, see Ishii, 1993; Lewis et al., 1993; Lindsay, 1994; Doré et al., 1997). Knock-out experiments revealed IGF-I as an important factor in neurogenesis and differentiation (for review, see Beck et al., 1995; Stewart and Rotwein, 1996). Moreover, IGF-I has neuroprotective properties as it reduces the programmed death of motoneurons during development, after axotomy and spinal cord transection (Lewis et al., 1993; Neff et al., 1993; Li et al., 1994). Besides that, intraventricular application of IGF-I attenuated neuronal cell loss after hypoxic-ischemic brain injury in adult rats (Guan et al., 1993; Tagami et al., 1997a,b).

More recent in vitro studies started to examine the mechanisms by which IGF-I exerts its antiapoptotic activity. Current understanding of IGF-mediated neuroprotection implies the activation

\footnotetext{
Received June 29, 1999; revised Oct. 15, 1999; accepted Oct. 22, 1999.

This work was supported by the Bundesministerium für Bildung und Forschung and Sonderforschungsbercich 430. M.B. was supported by the Herrmannand-Lilly-Schilling Foundation. We thank S. Thomsen for technical assistance and R. Ankerhold for critical discussion on this manuscript.

Correspondence should be addressed to Dr. Pawel Kermer, The Burnham Institute, Program on Cell Death and Apoptosis Research, 10901 North Torrey Pines Road, La Jolla, CA 92037. E-mail: pkermer@burnham-inst.org.

Copyright (C) 2000 Society for Neuroscience 0270-6474/00/200722-07\$15.00/0
}

phorylation after axotomy without treatment and an increased phosphorylation of Akt under treatment with IGF-I. This strong increase could be reduced by simultaneous injection of wortmannin (WM), a potent inhibitor of phosphatidylinositol 3-kinase (PI3-K). To prove the pathway suggested by these experiments as relevant for the in vivo situation, we assessed the number of RGCs $14 \mathrm{~d}$ after ON transection under a combined treatment strategy of IGF-I and WM. As expected, WM significantly reduced the neuroprotective effects of IGF-I. In summary, we show for the first time in vivo that IGF is neuroprotective via $\mathrm{PI} 3-\mathrm{K}-d e p e n d e n t$ Akt phosphorylation and by inhibition of caspase-3.

Key words: insulin-like growth factor-l; retinal ganglion cells; neuroprotection; PKB/Akt; PI3-K; caspase-3; apoptosis

of phosphatidylinositol 3-kinase (PI3-K), as demonstrated for cerebellar granule cells and sensory dorsal root ganglion cells (Alessi et al., 1996; Miller et al., 1997; Russell et al., 1998), which eventually leads to activation of protein kinase B (PKB/Akt) by phosphorylation (Franke et al., 1995; Alessi et al., 1997; Dudek et al., 1997; Nunez and del Peso, 1998). Active PKB in turn can phosphorylate and thereby inactivate the initiator caspase-9 (Cardone et al., 1998) and the proapoptotic protein Bad (Datta et al., 1997; del Peso et al., 1997). Because caspase-9 is a major activator of the downstream effector caspase-3 ( $\mathrm{Li}$ et al., 1997), reduced activity of the latter might account for the neuroprotection mediated by this pathway, which is in line with studies demonstrating that IGF-I effectively blocked caspase-3 activity in hippocampal neurons in vitro (Suzuki et al., 1998; Tamatani et al., 1998).

Despite the fact that the IGF-I receptor is expressed in retinal neurons (Waldbillig et al., 1988; Ocrant et al., 1989; Charkrabarti et al., 1991; Burren et al., 1996) and IGF-I is known as a proliferation and differentiation factor for the neural retina (Frade et al., 1996), nothing has been known so far about putative neuroprotective effects of IGF-I on axotomized adult rat retinal ganglion cells (RGCs) that mainly die by caspase-3-dependent apoptosis (Kermer et al., 1998, 1999a,b). In the present study, we injected IGF-I intraocularly after ON transection and assessed RGC survival $14 \mathrm{~d}$ after the lesion. Moreover, we investigated the signaling cascade by which IGF-I potentially mediates its neuroprotective effects in vivo.

\section{MATERIALS AND METHODS}

Surgery and retrograde labeling. Transection of the ON was performed as described previously (Kermer et al., 1998). Briefly, adult female Sprague Dawley rats (200-250 gm; Charles River Wiga, Sulzfeld, Germany) were 
anesthetized by intraperitoneal injection of chloral hydrate $(0.42 \mathrm{gm} / \mathrm{kg}$ of body weight). After skin incision close to the superior orbital rim, the orbita was opened taking care to leave the supraorbital vein intact. After subtotal resection of the lacrimal gland, the superior extraocular muscles were spread by means of a small retractor. The ON was exposed by longitudinal incision of the eye retractor muscle and the perineurium. Transection was performed $\sim 2 \mathrm{~mm}$ from the posterior eye pole without damaging retinal blood supply. Animals with persistent retinal ischemia verified fundoscopically were excluded. In a subset of animals assigned for the neuroprotection study, RGCs were retrogradely labeled by the fluorescent tracer fast blue (FB; Dr. Illing Chemie, Gross-Umstadt, Germany). Accurate and reproducible labeling was achieved by placing a small piece of gel foam soaked in $2 \%$ aqueous FB at the ocular stump of the axotomized ON.

Drug administration and tissue processing. IGF-I (Sigma, Deisenhofen, Germany) was dissolved in $0.1 \mathrm{~mm}$ acetic acid according to the manufacturer's instructions. Wortmannin (WM; Sigma) was dissolved in 100\% dimethylsulfoxide (DMSO; Sigma). Both solutions were further diluted in PBS. For intraocular drug injection, animals were anesthetized by diethylether. By means of a glass microelectrode with a tip diameter of 30 $\mu \mathrm{m}, 2 \mu \mathrm{l}$ of IGF and/or WM was injected into the vitreous space puncturing the eye at the cornea-sclera junction.

For the examination of neuroprotective effects, two different doses of IGF-I [ $2 \mu \mathrm{g}(n=6)$ or $5 \mu \mathrm{g}(n=4)$ per injection] were applied. Animals received either three intraocular injections of IGF-I on days 4, 7, and 10 after axotomy or an additional injection on day 0 immediately after surgery $(n=5)$. For combined IGF and WM treatment $(n=4)$, IGF injection $(5 \mu \mathrm{g})$ was followed by $2 \mu \mathrm{l}$ of $0.1 \mathrm{~mm} \mathrm{WM}$. Injection of vehicle (PBS; $n=4)$ or $0.1 \mathrm{mM} \mathrm{WM}$ alone $(n=3)$ served as control. Fourteen days after ON transection, animals received an overdose of chloral hydrate, and the eyes were removed. The retinae were dissected, flatmounted on gelatin-coated glass slides, and fixed for $20 \mathrm{~min}$ in $4 \%$ paraformaldehyde in PBS. RGCs were examined under the fluorescence microscope (Axiovert 35; Zeiss) with a UV filter $(365 / 420 \mathrm{~nm}$ ) for FB fluorescence. The number of FB-positive RGCs was determined according to a blind protocol published previously (Kermer et al., 1998; Klöcker et al., 1998).

For caspase-3 activity assay and Western blot analysis, animals were injected intraocularly on days 0 and 4 after the lesion. Animals received an overdose of chloral hydrate, and the eyes including the contralateral control eye were removed $\sim 6 \mathrm{hr}$ after the second caspase inhibitor injection on day 4.

Reverse transcription-PCR for caspase-3. For reverse transcription (RT)PCR experiments, dissected retinae were immediately snap-frozen in liquid nitrogen. Total RNA was extracted using Trizol reagent (Life Technologies) following the manufacturer's protocol. RT-PCR was performed according to standard protocols. For cDNA synthesis, $2.5 \mu \mathrm{g}$ of total RNA was reversely transcribed with Superscript II (Life Technologies) in a volume of $50 \mu \mathrm{l}$ according to the manufacturer's instructions. The reaction was primed using random primers (300 ng). For subsequent PCR reaction, $100 \mathrm{ng}$ of ethanol-precipitated cDNA was used as the template. The primer sequences and cycling conditions for semiquantitative PCR were the following: $94^{\circ} \mathrm{C}$ for $3 \mathrm{~min}$, annealing for $30 \mathrm{sec}$, and extension for $30 \mathrm{sec}$ at $72^{\circ} \mathrm{C}$; caspase- 3 primers, TACCCTGAAATGGGCTTGTGT (forward) and GTTAACACGAGTGAGGATGTG (reverse), annealing temperature of $50^{\circ} \mathrm{C}, 28$ cycles; glyceraldehyde-3phosphate dehydrogenase (G3PDH) primers, GTGATGCTGGTGCTGA (forward) and GCTAAGCAGTTGGTGG (reverse), annealing temperature of $50^{\circ} \mathrm{C}, 23$ cycles; and actin primers, CTACAATGAGCTGCGTGTGGC (forward) and CAGGTCCAGACGCAGGATGGC (reverse), annealing temperature of $55^{\circ} \mathrm{C}, 30$ cycles.

Caspase- 3 activity assay. Retinae were homogenized and lysed $(150 \mathrm{~mm}$ $\mathrm{NaCl}, 50 \mathrm{~mm}$ Tris, pH 8.0, 2 mm EDTA, and 1\% Triton, containing 0.1 $\mathrm{mM}$ PMSF and $2 \mu \mathrm{g} / \mathrm{ml}$ pepstatin, leupeptin, and aprotinin) for $10 \mathrm{~min}$ at $37^{\circ} \mathrm{C}$, and cell debris were pelleted at $13,000 \times g$ for $15 \mathrm{~min}$. The protein concentration of the supernatant was determined using the BCA reagent (Pierce, Rockford, IL).The caspase-3 fluorogenic activity assay was performed with $30 \mu$ of fresh protein lysates [ $\operatorname{control}(n=13)$; axotomy day $4(n=6)$; and axotomy day 4 treated with $5 \mu \mathrm{g}$ of IGF-I on days 0 and $4(n=4)]$ that were incubated with $100 \mu \mathrm{M}$ Ac-Asp-Glu-Val-AspAMC [acetyl-Asp-Glu-Val-Asp-amino-4-methylcoumarin (AcDEVD-AMC); Bachem], a fluorogenic substrate of caspase-3. Optical density (OD) was determined every $15 \mathrm{~min}$ for $2 \mathrm{hr}$ using $360 \mathrm{~nm}$ excitation and $460 \mathrm{~nm}$ emission wavelengths (CytoFlour 2350); caspase-3 activity was calculated as the increase in OD per microgram of protein over time. Statistics were performed applying one-way ANOVA followed by Duncan's test.

Western blot analysis. Tissue was processed as described above except for lysation that was performed on ice for $20 \mathrm{~min}$. After separation by reducing SDS-PAGE (Ausubel et al., 1987) of the lysates $(20 \mu \mathrm{g}$ of protein per lane), proteins were transferred to a polyvinylidene difluoride membrane and blocked with 5\% skim milk in $0.1 \%$ Tween 20 in PBS (PBS-T). The membranes were incubated with the primary antibody against phospho-Akt (New England Biolabs GmbH, Schwalbach, Germany; $1: 1000$ in 1\% skim milk in PBS-T). After washing in PBS-T, the membranes were incubated with HRP-conjugated secondary antibodies against rabbit IgG (Dianova, Hamburg, Germany; 1:2000 in PBS-T). Labeled proteins were detected using the ECL-plus reagent (Amersham, Arlington Heights, IL). All experiments for RT-PCR and Western blotting were performed with at least four animals and reproduced three times.

\section{RESULTS}

\section{IGF-I is a survival factor for axotomized RGCs in vivo}

Within $14 \mathrm{~d}$ after $\mathrm{ON}$ transection, as determined by retrograde FB labeling from the axon stump, no more than 339 with a SE of 43 RGCs per $\mathrm{mm}^{2}$ were detectable $(n=6$; Figs. 1,2$)$, which is $\sim 17 \%$ of controls (Kermer et al., 1998) (Fig. 2). To examine the potential neuroprotective effects of IGF-I on axotomized RGCs, we treated the animals intraocularly with IGF-I on days 4,7 , and 10 after the lesion. Compared with axotomy without therapy, IGF treatment significantly improved RGC survival in a dosedependent manner (Figs. 1, 2). Although $2 \mu \mathrm{g}$ of IGF-I per injection promotes survival up to $463 \pm 32$ cells per $\mathrm{mm}^{2} 14 \mathrm{~d}$ after the lesion $(n=6)$, the RGC number could be significantly further increased by $5 \mu \mathrm{g}$ of IGF-I per injection $(609 \pm 25 \mathrm{per}$ $\left.\mathrm{mm}^{2} ; n=4 ; p<0.05\right)$. Vehicle injection had no significant effect on RGC survival ( $379 \pm 56$ per $\left.\mathrm{mm}^{2} ; n=4\right)$. An additional intraocular injection of IGF-I ( $5 \mu \mathrm{g}$ per injection) on day 0 immediately after surgery resulted in an even higher RGC survival $14 \mathrm{~d}$ after the lesion $\left(661 \pm 49\right.$ per $\left.\mathrm{mm}^{2} ; n=5\right)$ but did not reach statistical significance when compared with treatment on days 4,7 , and 10 after axotomy.

\section{IGF-I blocks retinal caspase-3 activity after ON transection}

The activity of caspase- 3 was measured in the retinal tissue of controls and of animals with axotomy without therapy and under treatment with IGF-I on days 0 and 4 after ON transection to elucidate whether the neuroprotective effects of IGF-I rely on the inhibition of a downstream executioner of neuronal death in vivo. Because caspase-3 gets activated until day 4 after the lesion (Kermer et al., 1999b), we performed activity assays on postlesional day $4 \sim 6 \mathrm{hr}$ after the second IGF injection. As indicated in Figure 3, cleavage of the caspase-3-specific fluorogenic substrate Ac-DEVD-AMC in axotomized retinae was significantly increased by $43 \%(p<0.05)$ when compared with controls. Intraocular injection of IGF-I on days 0 and 4 after axotomy blocked this increased activity down to control levels, suggesting that inhibition of caspase- 3 is one possible mechanism by which IGF-I exerts its neuroprotective action in vivo. Figure 3 includes data of animals treated with the specific and irreversible inhibitor of caspase-3-like caspases benzyloxycarbonyl (z)DEVD-chloromethylketone (cmk) that inhibited caspase-3 activity more effectively (Kermer et al., 1998, 1999b).

\section{IGF-I does not induce changes in caspase-3 mRNA expression}

To study changes of caspase-3 mRNA expression under treatment with IGF-I, we used total retinal tissue for RT-PCR from postle- 

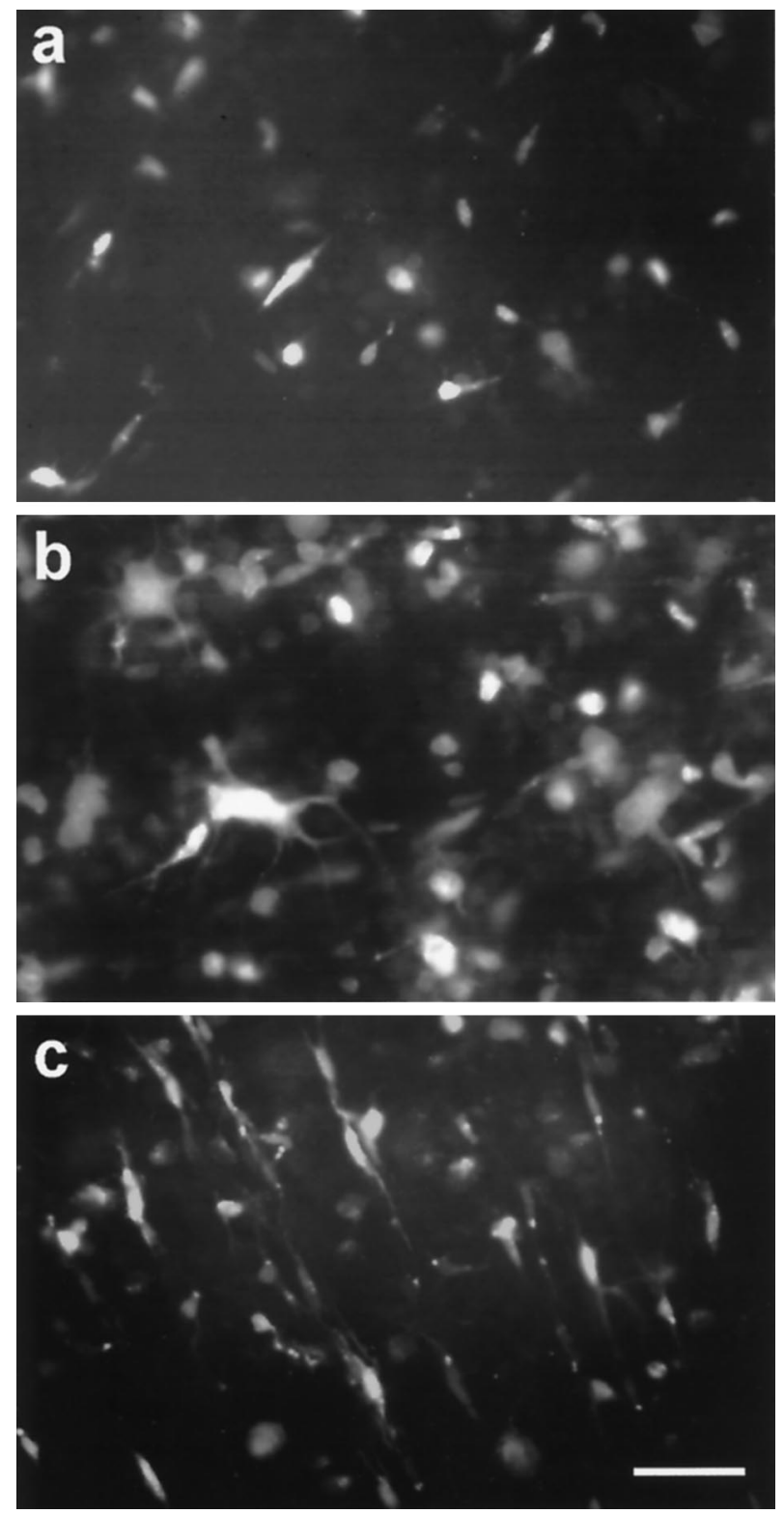

Figure 1. Retrogradely labeled RGCs. $a$, Axotomy without treatment. Note that only a few FB-labeled RGCs are detectable, and these appear shrunken and hardly display any dendritic processes. $b$, Axotomy intraocularly treated with $5 \mu \mathrm{g}$ of IGF-I on days $0,4,7$, and 10 after ON transection. RGC survival is significantly increased with many regularly shaped somata and dendrites. $c$, Combined treatment with $5 \mu \mathrm{g}$ of IGF-I and $0.1 \mathrm{mM} \mathrm{WM}$ on days $0,4,7$, and 10 after $\mathrm{ON}$ transection. Note that the neuroprotective effects of IGF-I are blocked by WM. Scale bar, $100 \mu \mathrm{m}$.

sional day 4 treated with $5 \mu \mathrm{g}$ of IGF-I on days 0 and 4 after ON transection. In agreement with our results comparing caspase-3 mRNA expression in axotomized but otherwise untreated retinae with corresponding contralateral controls at various time points after lesion (Kermer et al., 1999b), we were not able to detect any significant change in caspase-3 mRNA expression (Fig. 4). Densitometric analysis comparing caspase-3 mRNA expression with the expression of G3PDH and actin as housekeeping genes did not reveal any significant differences. Mean normalized values for caspase- 3 versus actin ( \pm SD) of the four IGF-treated animals and contralateral controls shown in Figure 4 were $4.353 \pm 0.56$ for IGF-I-treated and $4.295 \pm 0.32$ for contralateral control retinae.

\section{IGF-I induces Akt phosphorylation}

A potential pathway by which IGF-I exerts its neuroprotective effects was further examined by investigating the phosphorylation of PKB/Akt (Dudek et al., 1997). From in vitro studies it is known that caspase- 9 cleaves caspase- 3 in its active fragments ( $\mathrm{Li}$ et al., 1997). Phospho-Akt, representing the active form of PKB (for review, see Coffer et al., 1998), is able to phosphorylate and thereby inactivate Bad and caspase-9 (Datta et al., 1997; del Peso et al., 1997; Cardone et al., 1998), which in turn might finally prevent the cleavage and activation of caspase-3.

Western blot analysis of phospho-Akt was performed on day 4 after the lesion in retinal tissue of controls, axotomized retinae without treatment, and axotomized retinae treated with $5 \mu \mathrm{g}$ of IGF-I on days 0 and 4 after $\mathrm{ON}$ transection. As indicated in Figure $5 a$ and revealed by densitometric analysis of four paired samples in each experimental group (given in parentheses as the mean $\pm \mathrm{SD}$ ), axotomy without treatment resulted in a decreased Akt phosphorylation $(41.05 \pm 9.41)$ when compared with the corresponding contralateral control $(91.29 \pm 4.48)$. To conclude that this observation is not caused by decreased levels of the unphosphorylated, inactive Akt protein, we performed Western blots of murine Akt revealing no significant changes in Akt levels after axotomy (data not shown). In contrast, IGF-I treatment on days 0 and 4 after axotomy led to an increased phosphorylation of Akt in the lesioned eye $(106.04 \pm 22.28)$ when compared with the contralateral control $(43.73 \pm 2.68$; Fig. $5 b)$, whereas vehicle injection did not mimic this effect (data not shown).

\section{Akt gets phosphorylated in a PI3-K-dependent manner}

As is the case with other tyrosine kinase growth factor receptors, binding of IGF-I to the IGF-I receptor activates PI3-K in vitro (Miller et al., 1997; Russell et al., 1998). Moreover, Akt is established as a downstream effector of PI3-K (Franke et al., 1997; Coffer et al., 1998). Whether the PI3-K/Akt antiapoptoticsignaling pathway in vitro (Kennedy et al., 1997) reflects the in vivo situation was not known yet. WM, a naturally occurring inhibitor of PI3-K, is known to abolish Akt phosphorylation and neuroprotective effects in vitro (Alessi et al., 1996; Franke et al., 1997; Miller et al., 1997; Nunez and del Peso, 1998; Russell et al., 1998). Consequently, we examined whether injection of WM alone and in combination with IGF-I inhibits the induction of Akt phosphorylation. Figure 5, $c$ and $d$, illustrates our observations. Intraocular injection of various doses of WM in untreated control eyes effectively decreased Akt phosphorylation $(34.57 \pm 3.38$ vs $112.83 \pm 7.01$; Fig. $5 c$ ). For the combination study with $5 \mu \mathrm{g}$ of IGF-I we chose a WM concentration of $0.1 \mathrm{~mm}$. As shown in Figure $5 d$, an additional injection of $2 \mu$ l of $0.1 \mathrm{~mm} \mathrm{WM}$ on days 0 and 4 after the lesion immediately after application of IGF-I resulted in a clear decrease of Akt phosphorylation down to control levels $(82.79 \pm 6.28$ vs $93.97 \pm 14.56)$ when compared with IGF-I treatment alone (Fig. $5 b$ ). Thus, treatment with IGF-I seems to activate the PI3-K/Akt-signaling pathway in vivo.

\section{Wortmannin blocks neuroprotective effects of IGF-I}

The results demonstrated above clearly indicate that IGF-I induces the phosphorylation of Akt in a PI3-K-dependent manner. However, whether these results are of significance for the neuroprotective action of IGF-I in vivo was still speculative, because such changes could occur as epiphenomena. To prove significance of the suggested pathway in our model, we assessed RGC survival under a combined treatment of IGF-I and WM $(n=4)$. As indicated in Figures 1 and 6, an additional intraocular injection of 


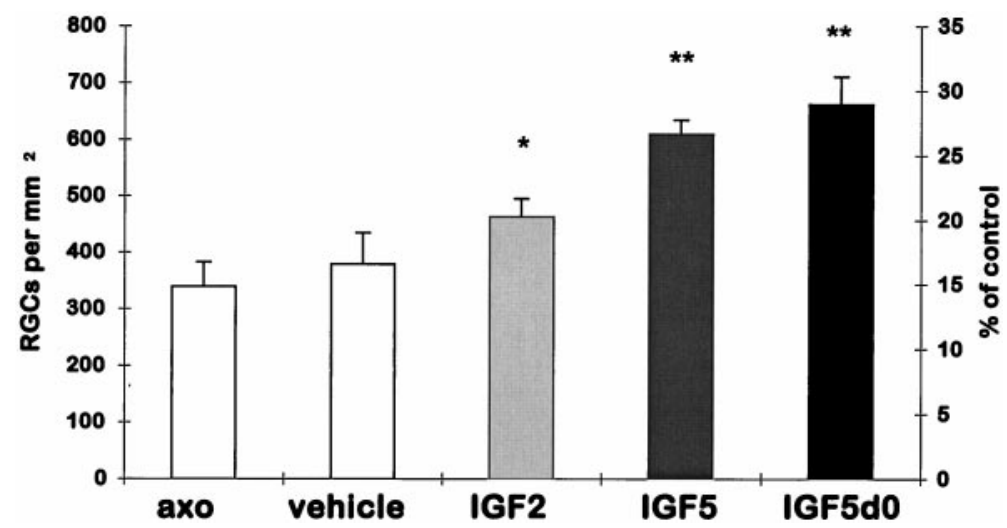

Figure 2. IGF-I is a survival factor for axotomized RGCs. Data are given as the mean ( \pm SEM) of retrogradely labeled RGCs per millimeter squared (left $y$-axis) or as the percentage of control retinae (right $y$-axis) $14 \mathrm{~d}$ after $\mathrm{ON}$ transection. Although vehicle treatment had no neuroprotective effects when compared with axotomy without treatment, intraocular injection of IGF-I on days 4, 7, and 10 after the lesion significantly increased the number of surviving RGCs in a dose-dependent manner. An additional injection on day 0 immediately after surgery further increased the number of RGCs per millimeter squared without reaching significant levels. axo, Axotomy without treatment; vehicle, treatment with vehicle on days $0,4,7$, and 10 after axotomy; IGF2, treatment with $2 \mu \mathrm{g}$ of IGF-I on days 4, 7, and 10 after axotomy; $I G F 5$, treatment with $5 \mu \mathrm{g}$ of IGF-I on days 4,7 , and 10 after axotomy; IGF5d0, treatment with $5 \mu \mathrm{g}$ of IGF-I on days $0,4,7$, and 10 after axotomy. ${ }^{*}$, Statistically significant when compared with axo ( $p<0.05$; one-way ANOVA followed by Duncan's test); **, statistically significant when compared with IGF2 $(p<0.05$; one-way ANOVA followed by Duncan's test).

$0.1 \mathrm{mM}$ WM significantly reduced the neuroprotective effects of IGF-I on RGCs 14 d after ON transection $(449 \pm 43$ vs $661 \pm 49$ RGCs per $\left.\mathrm{mm}^{2}\right)$. Treatment with $0.1 \mathrm{~mm} \mathrm{WM}$ alone $(n=3)$, however, did not alter the number of RGCs after axotomy (353 \pm $80 \mathrm{RGCs}$ per $\mathrm{mm}^{2}$ ). In reference to our blotting experiments (Fig. 5), these data suggest the IGF-I-induced, PI3-K-dependent Akt phosphorylation as one important pathway by which IGF-I exerts its survival effects on axotomized RGCs in vivo.

\section{DISCUSSION}

In this study, we present IGF-I as a trophic factor, which prevents secondary RGC death after axotomy. For the first time we give evidence that the neuroprotective action of IGF-I in vivo is most likely mediated by the antiapoptotic PI3-K/Akt pathway (Alessi et al., 1997; Franke et al., 1997; Coffer et al., 1998; Nunez and del Peso, 1998) and inhibition of caspase-3 activity.

Because of good surgical accessibility, the retinotectal projection in the rat serves as a convenient in vivo model to study degenerative and regenerative processes in the mammalian CNS (Villegas-Perez et al., 1988; Mey and Thanos, 1993; Bähr and Bonhoeffer, 1994; Berkelaar et al., 1994; Bähr and Wizenmann, 1996; Clarke et al., 1998; DiPolo et al., 1998; Chaudhary et al., 1999). The RGC population can easily be identified with similar labeling efficacy by retrograde tracing with fluorescent dyes either from the optic nerve stump or from both superior colliculi, which have been stereotactically injected in an additional intervention before ON transection (Bähr et al., 1992; Eschweiler and Bähr, 1993; Kermer et al., 1998; Klöcker et al., 1998). Axotomy of all RGCs by ON transection results in the delayed death of $\sim 80-$ $90 \%$ of RGCs within 14 d (Eschweiler and Bähr, 1993; MansourRobaey et al., 1994; Cui and Harvey, 1995). Experimental evidence indicates that this secondary death can primarily be ascribed to apoptosis (Garcia-Valenzuela et al., 1994; Rabacchi et al., 1994; Isenmann et al., 1997). Caspase-3, as a downstream effector of apoptosis, is activated selectively in axotomized RGCs and has been identified as an important mediator of secondary RGC death after axotomy (Kermer et al., 1998, 1999a,b). In addition to the very effective inhibition of caspase-3 applying specific inhibitors, various potential neuroprotective agents, such as brain-derived neurotrophic factor (BDNF), neurotrophin-4, and glial cell line-derived neurotrophic factor, have been shown previously to prevent secondary neuronal loss in our experimental paradigm (Mey and Thanos, 1993; Mansour-Robaey et al., 1994; Klöcker et al., 1997, 1998). In agreement with results obtained under therapy with BDNF (Klöcker et al., 1998) the rescue effects of IGF-I reported in the present study were dosedependent. In a first set of experiments we intraocularly injected $2 \mu \mathrm{g}$ of IGF-I on days 4, 7, and 10 after the lesion with significant neuroprotective effects. Applying a 2.5-fold higher concentration of IGF-I further increased the number of surviving RGCs significantly. However, as shown for BDNF (Mansour-Robaey et al., 1994), an early onset of treatment with an intraocular injection of IGF-I on day 0 immediately after $\mathrm{ON}$ transection had no additional effect on RGC survival $14 \mathrm{~d}$ after the lesion. At least for BDNF, this observation could be explained by an increased endogenous BDNF expression in the retina after lesion (Gao et al., 1997). That this increased expression holds true for IGF-I as well seems reasonable but needs further investigation.

The hypothesis that IGF-I might exert its neuroprotective effects via the inhibition of caspase activity was based on the observation that a combined treatment strategy of a neurotrophic factor with the irreversible inhibitor of caspase-3-like proteases z-DEVD-cmk revealed no increased survival of axotomized RGCs compared with single-drug therapy (Klöcker et al., 1999). Consequently, we measured the activity of caspase- 3 by studying
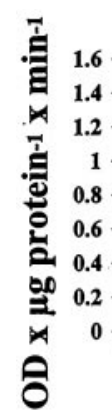

(1)
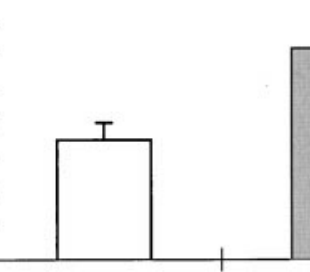

control
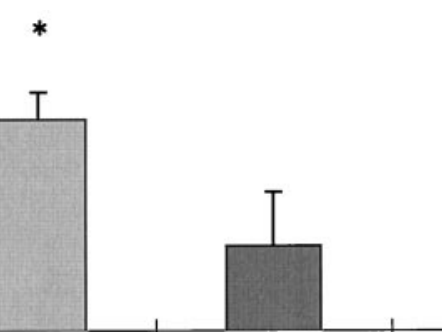

DEVD
Figure 3. Caspase-3 activity after axotomy and under IGF treatment. Data are given as the mean OD units ( \pm SEM) per minute and microgram of protein as a measurement of AcDEVD-AMC cleavage by active caspase-3. Compared with that of control retinae, the activity of caspase- 3 on day 4 after $\mathrm{ON}$ transection (axo) is significantly increased. Intraocular injection of $5 \mu \mathrm{g}$ of IGF-I on days 0 and 4 after the lesion (IGF) results in a strong reduction of caspase-3 activity down to control levels. Treatment with z-DEVD-cmk (DEVD), a potent inhibitor of caspase-3-like proteases, inhibited caspase-3 activity more effectively, reflecting a higher neuroprotective activity (Kermer et al., 1998). *, Statistically significant when compared with control $(p<0.05)$. 
IGF C IGF C IGF C IGF C

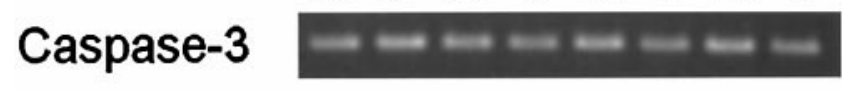

G3PDH
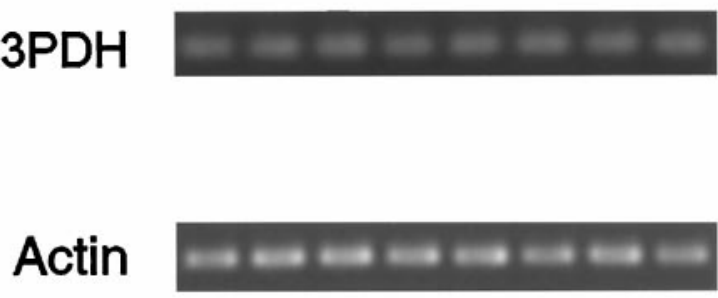

Figure 4. Caspase-3 mRNA under treatment with IGF-I. Retinal caspase- 3 mRNA expression on day 4 after axotomy treated with $5 \mu \mathrm{g}$ of IGF-I on postlesional days 0 and $4(I G F)$ compared with that of control retinae $(C)$. In none of the investigated animals were significant changes in caspase-3 mRNA levels detectable. The corresponding expression of G3PDH and actin mRNA as housekeeping genes is shown below.

the cleavage of the fluorogenic substrate Ac-DEVD-AMC (Kermer et al., 1999b) under treatment with IGF-I. As shown by in vitro studies of other investigators (Suzuki et al., 1998; Tamatani et al., 1998), we were able to demonstrate an increased
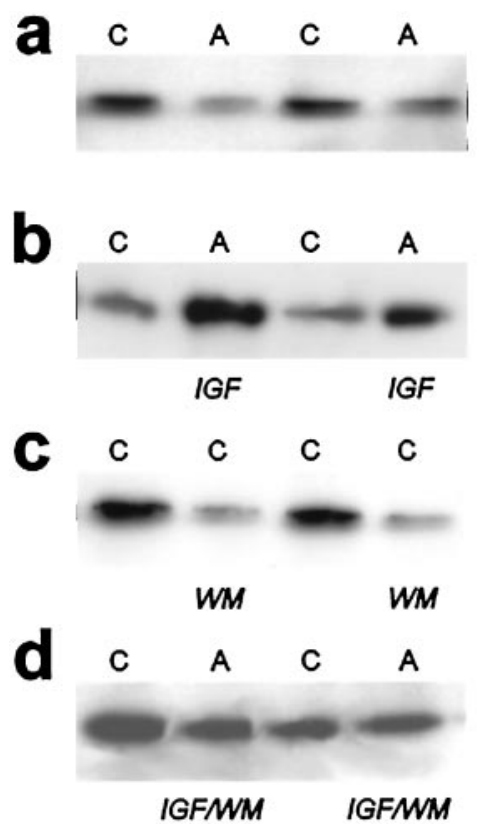

Figure 5. Western blot analysis of phospho-Akt. $a-d$, Each panel shows axotomized and/or contralateral control retinae of two independent animals in the various experimental groups. $a$, Axotomy without treatment on day 4 after the lesion $(A)$ compared with the corresponding contralateral control retina $(C)$. Note the strong decrease of phospho-Akt after axotomy. $b$, Axotomy treated with $5 \mu \mathrm{g}$ of IGF-I (A; IGF below) on postlesional days 0 and 4 compared with the corresponding contralateral control retina $(C)$. Note the massive increase of phospho-Akt in axotomized retinae under IGF treatment. $c$, Control retina treated with $0.1 \mathrm{~mm}$ WM ( $C$; WM below) on postlesional days 0 and 4 compared with the corresponding contralateral control $(C)$. Note the decrease of phosphoAkt in the control under treatment with WM. $d$, Axotomy treated with 5 $\mu \mathrm{g}$ of IGF-I and $0.1 \mathrm{~mm} \mathrm{WM}(A ; I G F / W M$ below $)$ on postlesional days 0 and 4 compared with the corresponding contralateral control $(C)$. Note the inhibition of Akt phosphorylation down to control levels.

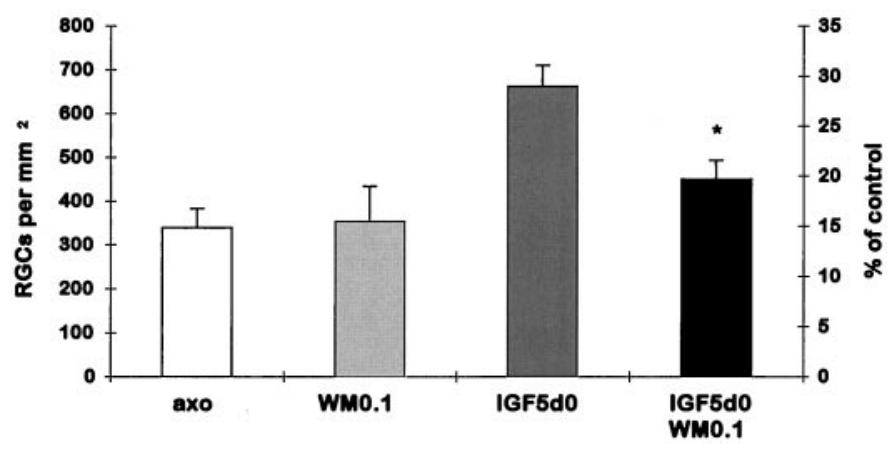

Figure 6. Wortmannin blocks neuroprotective effects of IGF-I. Data are given as the mean ( \pm SEM) of retrogradely labeled RGCs per millimeter squared (left $y$-axis) or as the percentage of control (right $y$-axis) $14 \mathrm{~d}$ after $\mathrm{ON}$ transection. Although intraocular injection of $0.1 \mathrm{~mm}$ wortmannin on days $0,4,7$, and 10 after axotomy (WM0.1) did not alter the number of surviving RGCs when compared with axotomy without treatment (axo), treatment with $5 \mu \mathrm{g}$ of IGF-I on days $0,4,7$, and 10 after ON transection $(I G F 5 d 0)$ resulted in an significantly increased survival rate of RGCs (compare Fig. 1). These neuroprotective effects were significantly reduced by an additional injection of $0.1 \mathrm{mM}$ WM directly after each IGF treatment (IGF5d0 WM0.1). *, Statistically significant when compared with IGF5d0 ( $p<0.05$; one-way ANOVA followed by Duncan's test).

activation of caspase- 3 on day 4 after lesion in vivo that could be effectively inhibited by treatment with IGF-I. In agreement with the lower neuroprotective effects of IGF-I, reduction of caspase-3 activity was not as effective as that observed under z-DEVD-cmk treatment (Fig. 3; Kermer et al., 1998, 1999b). Postlesional day 4 was chosen for these experiments because we had shown previously that a significant increase in caspase-3 activity after ON transection first occurs on day 4 (Kermer et al., 1999b). To test whether IGF-I might induce the inhibition of caspase-3 activity by decreasing the expression of caspase- 3 mRNA, we additionally performed RT-PCR for caspase- 3 on day 4 after ON transection. In agreement with results comparing control retinae with untreated retinae after axotomy by RT-PCR and in situ hybridization (Chaudhary et al., 1999; Kermer et al., 1999b), we were not able to detect significant changes in caspase-3 mRNA expression when comparing axotomized retinae under IGF-I treatment on day 4 after the lesion with the corresponding contralateral control retinae. Because we failed to detect a significant regulation, we hypothesized that IGF-I treatment decreases caspase-3 activity on the translational or post-translational level. However, it should be noted that the lack of mRNA regulation in our lesion paradigm could also be explained by the fact that the RGC population represents only $\sim 0.57 \%$ of the entire retinal tissue (Simon and Thanos, 1998). Thus, modest changes in caspase-3 mRNA expression in single cells might escape detection by RT-PCR of total retinal tissue.

Because caspase- 3 activity in our model is regulated on the translational or post-translational level, it seemed reasonable to expect a signaling pathway by which binding of IGF-I to its receptor finally inhibits caspase-3 activity (Kulik et al., 1997). Recently, it was shown that phosphorylation of unprocessed or active caspase- 9 by active $\mathrm{PKB} / \mathrm{Akt}$ results in an inactivation of this zymogen (Cardone et al., 1998). Because caspase-3 represents a major downstream substrate of caspase-9 (Li et al., 1997), the inactivation of caspase- 9 might lead to decreased activation of caspase-3. Whereas the activation and inhibition of caspase- 9 as a potential link between neuroprotective pathways and downstream caspase-3 activity in our lesion model are under current investi- 
gation, we here examined the phosphorylation of $\mathrm{PKB} / \mathrm{Akt}$ as a part of the antiapoptotic PI3-K/Akt pathway (Franke et al., 1995, 1997; Alessi et al., 1996; Kennedy et al., 1997; Shimoke et al., 1998) after ON transection in more detail. By Western blot analysis using an antibody against active phospho-Akt, we first compared axotomy without treatment with contralateral controls. Interestingly, we observed a decreased phosphorylation of Akt in axotomized retinae. In contrast, IGF-I treatment resulted in a massive induction of phospho-Akt in lesioned retinal tissue. To date, the explanation of decreased phospho-Akt levels in axotomized retinae remains speculative. We could exclude decreased levels of the murine Akt protein after axotomy as a trivial explanation for this observation. Because several neurotrophic factors are able to phosphorylate Akt (Coffer et al., 1998), the interrupted retrograde transport of neurotrophic factors from the superior colliculus, the target of the retinotectal projection, might serve as another explanation. However, the neurotrophic hypothesis (Barde, 1989) seems unlikely to be the only possible explanation because, as stated above, at least BDNF is upregulated in RGCs after ON transection (Gao et al., 1997). On the other hand, sustained or elevated intracellular calcium levels, for example, influence the activity of PI3-K (Scharenberg and Kinet, 1998), which might be the regulatory element resulting in decreased levels of phospho-Akt after axotomy (Franke et al., 1997; Nunez and del Peso, 1998). Nevertheless, decreased intracellular levels of phospho-Akt may result in increased levels of active Bad or caspase-9 and subsequently increased activity of caspase-3, whereas increased phospho-Akt levels under treatment with IGF-I are accompanied by a reduced activity of caspase- 3 and a reduced RGC death. Making the scenario more complex, it should be noted that there are several processes under physiological conditions in which a role for Akt has been implicated, including intermediary metabolism and protein synthesis (for review, see Coffer et al., 1998). Because the axotomy-induced signal causing secondary RGC death is not yet known, more detailed studies are necessary dealing with the intracellular processes after lesion.

To complete the investigation of the PI3-K/Akt pathway in our model, we demonstrated that the phosphorylation of Akt depends on the activation of PI3-K. Several in vitro studies suggested that treatment with the PI3-K inhibitor wortmannin abolished the neuroprotective effects of IGF-I (Alessi et al., 1996; Dudek et al., 1997; Miller et al., 1997; Russell et al., 1998). Additional intraocular injection of WM in IGF-treated retinae on days 0 and 4 after the lesion reduced Akt phosphorylation to control levels. These data suggest that after binding of IGF-I to its tyrosine kinase domain-containing receptor molecule, downstream events including the phosphorylation of Akt are controlled by PI3-K (Franke et al., 1997; Scharenberg and Kinet, 1998). We are aware that we provide only indirect evidence of this antiapoptotic pathway being selectively activated in axotomized RGCs. However, taking into account that caspase-3 is activated selectively in RGCs after ON transection (Kermer et al., 1999b) and that this is the only cell type affected by the lesion directly, it seems reasonable to assume that IGF-induced Akt phosphorylation occurs in RGCs. Nevertheless, to prove this pathway as a predominant mechanism of IGF-I-induced neuroprotection in our in vivo model, we finally assessed the number of RGCs $14 \mathrm{~d}$ after axotomy under a combined treatment strategy of IGF-I and WM. As hypothesized, the positive effects of IGF-I on the survival of axotomized RGCs in vivo could be significantly blocked by inhibition of PI3-K.

Taken together, the results discussed above show for the first time that IGF-I is a survival factor for axotomized RGCs in vivo. Moreover, this is the first study that demonstrates that the PI3K-dependent Akt phosphorylation and reduced caspase-3 activity are important in vivo mechanisms by which IGF-I mediates its neuroprotective action. Future studies are necessary to examine the possible role of caspase- 9 and the proapoptotic protein Bad as a connection between the antiapoptotic PI3-K/Akt pathway and downstream caspase- 3 activity in this model.

\section{REFERENCES}

Alessi DR, Andjelkovic M, Caudwell B, Cron P, Morrice N, Cohen P, Hemmings BA (1996) Mechanism of activation of protein kinase B by insulin and IGF-1. EMBO J 15:6541-6551.

Alessi DR, James SR, Downes CP, Holmes AB, Gaffney PR, Reese CB, Cohen P (1997) Characterization of a 3-phosphoinositide-dependent protein kinase which phosphorylates and activates protein kinase Balpha. Curr Biol 7:261-269.

Ausubel FM, Brent R, Klingston RE, Moore DD, Seidman JG, Smith JA, Struhl K (1987) Current protocols in molecular biology. New York: Wiley.

Bähr M, Bonhoeffer F (1994) Perspectives on axonal regeneration in the mammalian CNS. Trends Neurosci 17:473-479.

Bähr M, Wizenmann A (1996) Retinal ganglion cell axons recognize specific guidance cues present in the deafferented adult rat superior colliculus. J Neurosci 16:5106-5116.

Bähr M, Eschweiler GW, Wolburg H (1992) Precrushed sciatic nerve grafts enhance the survival and axonal regrowth of retinal ganglion cells in adult rats. Exp Neurol 166:13-22.

Barde YA (1989) Trophic factors and neuronal survival. Neuron 2:1525-1534.

Beck KD, Powell Braxton L, Widmer HR, Valverde J, Hefti F (1995) Igf1 gene disruption results in reduced brain size, CNS hypomyelination, and loss of hippocampal granule and striatal parvalbumincontaining neurons. Neuron 14:717-730.

Berkelaar M, Clarke DB, Wang YC, Bray GM, Aguayo AJ (1994) Axotomy results in delayed death and apoptosis of retinal ganglion cells in adult rats. J Neurosci 14:4368-4374.

Burren CP, Berka JL, Edmondson SR, Werher GA, Batch JA (1996) Localization of mRNAs for insulin-like growth factor-I (IGF-I), IGF-I receptor, and IGF binding proteins in rat eye. Invest Ophthalmol Vis Sci 37:1459-1468.

Cardone MH, Roy N, Stennicke HR, Salvesen GS, Franke TF, Stanbridge E, Frisch S, Reed JC (1998) Regulation of cell death protease caspase- 9 by phosphorylation. Science 282:1318-1321.

Charkrabarti S, Ghahary A, Murphy LJ, Sima AA (1991) Insulin-like growth factor-I expression is not increased in the retina of diabetic BB/W-rats. Diabetes Res Clin Pract 14:91-97.

Chaudhary P, Ahmed F, Ouebada P, Sharma SC (1999) Caspase inhibitors block the retinal ganglion cell death following optic nerve transection. Mol Brain Res 67:36-45.

Clarke DB, Bray GM, Aguayo AJ (1998) Prolonged administration of NT-4/5 fails to rescue most axotomized retinal ganglion cells in adult rats. Vision Res 38:1517-1524.

Coffer PJ, Jin J, Woodgett JR (1998) Protein kinase B (c-Akt): a multif unctional mediator of phosphatidylinositol 3-kinase activation. Biochem J 335:1-13.

Cui Q, Harvey AR (1995) At least two mechanisms are involved in the death of retinal ganglion cells following target ablation in neonatal rats. J Neurosci 15:8143-8155.

Datta SR, Dudek H, Tao X, Masters S, Fu H, Gotoh Y, Greenberg ME (1997) Akt phosphorylation of BAD couples survival signals to the cell-intrinsic death machinery. Cell 91:231-241.

Daughaday WH, Rotwein P (1989) Insulin-like growth factors I and II. Peptide, messenger ribonucleic acid and gene structure, serum and tissue concentrations. Endocr Rev 10:68-91.

Daughaday WH, Hall K, Raben MS, Salmon Jr WD, Brande JL, Wyk JJ (1972) Somatomedin: proposed designation for sulphation factor. Nature 235:107.

del Peso L, Gonzalez Garcia M, Page C, Herrera R, Nunez G (1997) Interleukin-3-induced phosphorylation of BAD through the protein kinase Akt. Science 278:687-689.

DiPolo A, Aigner LJ, Dunn RJ, Bray GM, Aguayo AJ (1998) Prolonged delivery of brain-derived neurotrophic factor by adenovirus-infected 
Mueller cells temporarily rescues injured retinal ganglion cells. Proc Natl Acad Sci USA 95:3978-3983.

Doré S, Kar S, Quirion R (1997) Rediscovering an old friend, IGF-I: potential use in the treatment of neurodegenerative diseases. Trends Neurosci 20:326-331.

Dudek H, Datta SR, Franke TF, Birnbaum MJ, Yao R, Cooper GM, Segal RA, Kaplan DR, Greenberg ME (1997) Regulation of neuronal survival by the serine-threonine protein kinase Akt [see comments]. Science 275:661-665.

Eschweiler GW, Bähr M (1993) Flunarizine enhances rat retinal ganglion cell survival after axotomy. J Neurol Sci 116:34-40.

Frade JM, Marti E, Bovolenta P, Rodriguez Pena MA, Perez Garcia D, Rohrer H, Edgar D, Rodriguez Tebar A (1996) Insulin-like growth factor-I stimulates neurogenesis in chick retina by regulating expression of the alpha 6 integrin subunit. Development 122:2497-2506.

Franke TF, Yang SI, Chan TO, Datta K, Kazlauskas A, Morrison DK, Kaplan DR, Tsichlis PN (1995) The protein kinase encoded by the Akt proto-oncogene is a target of the PDGF-activated phosphatidylinositol 3-kinase. Cell 81:727-736.

Franke TF, Kaplan DR, Cantley LC (1997) PI3K: downstream AKT ion blocks apoptosis. Cell 88:435-437.

Gao H, Qiao X, Hefti F, Hollyfield JG, Knusel B (1997) Elevated mRNA expression of brain-derived neurotrophic factor in retinal ganglion cell layer after optic nerve injury. Invest Ophthalmol Vis Sci 38:1840-1847.

Garcia-Valenzuela E, Gorczyca W, Darzynkiewicz Z, Sharma SC (1994) Apoptosis in adult retinal ganglion cells after axotomy. J Neurobiol 25:431-438.

Guan J, Williams C, Gunning M, Mallard C, Gluckman P (1993) The effects of IGF-1 treatment after hypoxic-ischemic brain injury in adult rats. J Cereb Blood Flow Metab 13:609-616.

Isenmann S, Wahl C, Krajewski S, Reed JC, Bähr M (1997) Upregulation of Bax protein in degenerating retinal ganglion cells precedes apoptotic cell death after optic nerve lesion in the rat. Eur J Neurosci 9:1763-1772.

Ishii DN (1993) Neurobiology of insulin and insulin-like growth factors. In: Neurotrophic factors (Loughlin SE, Fallon JH, eds), pp 415-442. San Diego: Academic.

Kennedy SG, Wagner AJ, Conzen SD, Jordan J, Bellacosa A, Tsichlis PN, Hay N (1997) The PI 3-kinase/Akt signaling pathway delivers an antiapoptotic signal. Genes Dev 11:701-713.

Kermer P, Klöcker N, Labes M, Bähr M (1998) Inhibition of CPP32-like proteases rescues axotomized retinal ganglion cells from secondary cell death in vivo. J Neurosci 18:4656-4662.

Kermer P, Klöcker N, Bähr M (1999a) Long-term effect of inhibition of ced 3-like caspases on the survival of axotomized retinal ganglion cells in vivo. Exp Neurol 158:202-205.

Kermer P, Klöcker N, Labes M, Thomsen S, Srinivasan A, Bähr M (1999b) Activation of caspase-3 in axotomized rat retinal ganglion cells in vivo. FEBS Lett 453:361-364.

Klöcker N, Bräunling F, Isenmann S, Bähr M (1997) In vivo neurotrophic effects of GDNF on axotomized retinal ganglion cells. NeuroReport 8:3439-3442.

Klöcker N, Cellerino A, Bähr M (1998) Free radical scavenging and inhibition of nitric oxide synthase potentiates the neurotrophic effects of brain-derived neurotrophic factor on axotomized retinal ganglion cells in vivo. J Neurosci 18:1038-1046.

Klöcker N, Kermer P, Weishaupt J, Labes M, Bahr M (1999) BDNF inhibits caspase-3 activity in axotomized retinal ganglion cells in vivo. Soc Neurosci Abstr 25:199.14.

Kulik G, Klippel A, Weber MJ (1997) Antiapoptotic signalling by the insulin-like growth factor I receptor, phosphatidylinositol 3-kinase, and Akt. Mol Cell Biol 17:1595-1606.

Lewis ME, Neff NT, Contreras PC, Stong DB, Oppenheim RW, Grebow PE, Vaught JL (1993) Insulin-like growth factor-I: potential for treatment of motor neuronal disorders. Exp Neurol 124:73-88.

Li L, Oppenheim RW, Lei M, Houenou LJ (1994) Neurotrophic agents prevent motoneuron death following sciatic nerve section in the neonatal mouse. J Neurobiol 25:759-766.

Li P, Nijhawan D, Budihardjo I, Srinivasula SM, Ahmad M, Alnemri ES, Wang X (1997) Cytochrome $c$ and dATP-dependent formation of Apaf-1/caspase-9 complex initiates an apoptotic protease cascade. Cell 91:479-489.
Lindsay RM (1994) Trophic protection of motor neurons: clinical potential in motor neuron diseases. J Neurol 242[Suppl 1]:S8-S11.

Mansour-Robaey S, Clarke DB, Wang YC, Bray GM, Aguayo AJ (1994) Effects of ocular injury and administration of brain-derived neurotrophic factor on survival and regrowth of axotomized retinal ganglion cells. Proc Natl Acad Sci USA 91:1632-1636.

Mey J, Thanos S (1993) Intravitreal injections of neurotrophic factors support the survival of axotomized retinal ganglion cells in adult rats in vivo. Brain Res 602:304-317.

Miller TM, Tansey MG, Johnson Jr EM, Creedon DJ (1997) Inhibition of phosphatidyl-inositol 3-kinase activity blocks depolarization- and insulin-like growth factor I-mediated survival of cerebellar granule cells. J Biol Chem 272:9847-9853.

Neff NT, Prevette D, Houenou LJ, Lewis ME, Glicksman MA, Yin QW, Oppenheim RW (1993) Insulin-like growth factors: putative musclederived trophic agents that promote motoneuron survival. J Neurobiol 24:1578-1588.

Nunez G, del Peso L (1998) Linking extracellular survival signals and the apoptotic machinery. Curr Opin Neurobiol 8:613-618.

Ocrant I, Vanlentino KL, King MG, Wimpy TH, Rosenfeld RG, Baskin DG (1989) Localization and structural characterization of insulin-like growth factor receptors in mammalian retina. Endocrinology 125:2407-2413.

Rabacchi SA, Bonfanti L, Liu XH, Maffei L (1994) Apoptotic cell death induced by optic nerve lesion in the neonatal rat. J Neurosci 14:5292-5301.

Russell JW, Windebank AJ, Schenone A, Feldman EL (1998) Insulinlike growth factor-I prevents apoptosis in neurons after nerve growth factor withdrawal. J Neurobiol 36:455-467.

Salmon WD, Daughaday WH (1957) A hormonally controlled serum factor which stimulates sulfate incorporation by cartilage in vitro. J Lab Clin Med 49:825-836.

Scharenberg AM, Kinet JP (1998) PtdIns-3,4,5-P3: a regulatory nexus between tyrosine kinases and sustained calcium signals. Cell 94:5-8.

Shimoke K, Yamada M, Ikeuchi T, Hatanaka H (1998) Synthetic lipid products of PI3-kinase which are added to culture medium prevent low $\mathrm{K}+$-induced apoptosis of cerebellar granule neurons via Akt kinase activation. FEBS Lett 437:221-224.

Simon P, Thanos S (1998) Combined methods of retrograde staining, layer-separation and viscoelastic cell stabilization to isolate retinal ganglion cells in adult rats. J Neurosci Methods 83:113-124.

Stewart CE, Rotwein P (1996) Growth, differentiation, and survival: multiple physiological functions for insulin-like growth factors. Physiol Rev 76:1005-1026.

Suzuki J, Kaziro Y, Koide H (1998) Synergistic action of R-Ras and IGF-1 on Bcl-xL expression and caspase- 3 inhibition in BaF3 cells: R-Ras and IGF-1 control distinct anti-apoptotic kinase pathways. FEBS Lett 437:112-116.

Tagami M, Yamagata K, Nara Y, Fujino H, Kubota A, Numano F, Yamori Y (1997a) Insulin-like growth factors prevent apoptosis in cortical neurons isolated from stroke-prone spontaneously hypertensive rats. Lab Invest 76:603-612.

Tagami M, Ikeda K, Nara Y, Fujino H, Kubota A, Numano F, Yamori Y (1997b) Insulin-like growth factor-1 attenuates apoptosis in hippocampal neurons caused by cerebral ischemia and reperfusion in strokeprone spontaneously hypertensive rats. Lab Invest 76:613-617.

Tamatani M, Ogawa S, Tohyama M (1998) Roles of Bcl-2 and caspases in hypoxia-induced neuronal cell death: a possible neuroprotective mechanism of peptide growth factors. Brain Res Mol Brain Res 58:27-39.

Ullrich A, Gray A, Tam AW, Yang Feng T, Tsubokawa M, Collins C, Henzel W, Le Bon T, Kathuria S, Chen E, et al. (1986) Insulin-like growth factor I receptor primary structure: comparison with insulin receptor suggests structural determinants that define functional specificity. EMBO J 5:2503-2512.

Villegas-Perez MP, Vidal Sanz M, Bray GM, Aguayo AJ (1988) Influences of peripheral nerve grafts on the survival and regrowth of axotomized retinal ganglion cells in adult rats. J Neurosci 8:265-280.

Waldbillig RJ, Fletcher RT, Somers RL, Chader GJ (1988) IGF-I receptors in the bovine neural retina: structure, kinase activity and comparison with retinal insulin receptors. Exp Eye Res 47:587-607. 